\title{
Karakteristik Fisiko-kimia Tepung Ubi Jalar Ungu dengan Proses Perendaman Menggunakan Asam Sitrat
}

\author{
Imam Santosa ${ }^{\mathrm{a}, 1, *}$, A.M. Puspa ${ }^{\mathrm{b}, 2}$, D. Aristianingsih ${ }^{\mathrm{b}, 3}$, Endah Sulistiawati ${ }^{\mathrm{b}, 4}$ \\ ${ }^{a, b}$ Program Studi Teknik Kimia, Fakultas Teknologi Industri, Universitas Ahmad Dahlan, Jl. Ring Road Selatan, Tamanan, Banguntapan, Bantul \\ Yogyakarta 55166. \\ ${ }^{1}$ imam.santosa@che.uad.ac.id
}

ARTICLE INFO

Article history

Received December 14, 2018

Revised September 05, 2019

Accepted September 05, 2019

Keywords

Tepung Ubi Jalar Ungu

Fisiko-Kimia

Asam Sitrat

\section{ABSTRACT}

A study has been made in making purple sweet potato flour through the hydrolysis process using dilute citric acid. Sweet potatoes cut 3-5 mm, soaked in citric acid in various concentrations for a certain period of time, washed and drained. Sweet potatoes were then roasted at 70 degrees Celsius for 24 hours and then sieved with a mesh size of 200 . The sieve results were analyzed for their physical physicochemical content and compared with wheat flour. Soaking purple sweet potato using $0.01 \%$ citric acid produces purple sweet potato flour which is brightly colored, fine flour, decreasing the ash content with a very slight acid flour odor. The carbohydrate content of sweet potatoes is almost the same as wheat flour and the fiber content of sweet potatoes is higher.

This is an open-access article under the CC-BY-SA license.

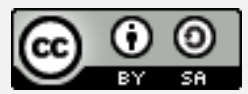

\section{Pendahuluan}

Menurut Food and Drug Administration (FDA) atau Badan Pengawas Obat dan Makanan Amerika Serikat asam sitrat merupakan bahan pengawet yang dinyatakan benar-benar aman untuk dikonsumsi. Asam sitrat masih berdekatan dengan vitamin C dan sama-sama merupakan pengawet alami yang baik.

Asam sitrat merupakan senyawa intermediet dari asam organik yang mampu mengkompleks ion tembaga yang berperan sebagai katalis dalam reaksi pencoklatan (browning). Selain itu, asam sitrat juga dapat menghambat pencoklatan dengan cara menurunkan $\mathrm{pH}$ dibawah 3 sehingga enzim polifenol oksidase menjadi inaktif [1]. Keasaman asam sitrat didapatkan dari tiga gugus karboksilat $\mathrm{COOH}$ yang dapat melepas proton $\left(\mathrm{H}^{+}\right)$dalam larutan. Ion $\mathrm{H}^{+}$pertama akan dilepas pada $\mathrm{pH} 3, \mathrm{H}^{+}$ kedua dilepas pada $\mathrm{pH} 7$ dan $\mathrm{H}^{+}$ketiga dilepas pada $\mathrm{pH}$ 10. Proton sudah dilepas dalam larutan yang sangat asam. Dalam keadaan ini yang tersisa adalah liganoksida, yang akan dilepaskan jika ion pusat tereduksi menjadi bervalensi yang lebih rendah [2].

Penelitian untuk mengevaluasi potensi asam sitrat dan askorbat sebagai bahan anti browning juga telah dilakukan oleh Abbasi [3] pada buah loquat. Pada konsentrasi yang lebih tinggi (700 mg/l) asam askorbat lebih efektif dalam mempertahankan kualitas buah dari pada asam sitrat dan mampu mengurangi browning. Selanjutnya efek asam sitrat, asam askorbat dan kalsium klorida terhadap warna dan kualitas organolitik kol potong segar pada konsentrasi oksigen yang rendah $(1,5 \%)$ dan kualitas visual. Kombinasi temperatur rendah dengan Modified Atmosphere Packaging (MAP) dan perlakuan asam sitrat memperpanjang umur kol menjadi 22 hari.

Tepung ubi jalar mentah memberikan after taste pahit pada produk akhir sehingga dapat mengganggu cita rasa produk. Rasa pahit biasanya disebabkan oleh beberapa senyawa fenolik atau 
alkaloid [4]. Adapun karakteristik fisiko-kimia tepung ubi jalar yang dihasilkan di Indonesia terdapat pada tabel 1 .

Table 1. Karakteristik Fisiko-Kimia Tepung Ubi Jalar yang Dihasilkan di Indonesia

\begin{tabular}{llllc}
\hline \multirow{2}{*}{ Komposisi Kimia } & \multicolumn{3}{c}{ Warna Umbi } & \multirow{2}{*}{ Rata-rata } \\
\cline { 2 - 5 } & Putih & Kuning & Ungu & 7,94 \\
\hline Air (\%) & 10,99 & 6,77 & 7,00 & 3,94 \\
\hline Abu (\%) & 3,14 & 4,71 & 5,31 & 0,82 \\
\hline Lemak (\%) & 1,02 & 0,91 & 0,81 & 3,44 \\
\hline Protein (\%) & 4,46 & 4,42 & 2,79 & 4,42 \\
\hline Serat kasar (\%) & 4,44 & 5,54 & 4,72 & 83,39 \\
\hline Karbohidrat (\%) & 84,83 & 83,19 & 83,81 & . \\
\hline
\end{tabular}

Untuk mencegah terbentuknya warna gelap pada tepung ubi jalar karena aktivitas enzim polifenol oksidase, sawut ubi jalar direndam dalam larutan natrium bisulfit $0,2 \%$ berat/berat selama 10-15 menit dengan perbandingan volume air rendaman dan umbi 3 liter : $1 \mathrm{~kg}$ [6]. Residu sulfit ini relatif kecil (11,4 ppm) pada tepung ubi jalar ungu klon MSU 03028-10 [7] dan masih dibawah batas maksimal yang diijinkan untuk bahan pangan, yakni 200 ppm. Rendemen tepung ubi jalar ungu asal klon MSU 03028-10 dilaporkan 29\%, cukup tinggi dibandingkan dengan rendemen tepung yang berkisar antara 18-30\% dari beberapa varietas ubi jalar putih dan kuning [8]. Menurut Kusumawardani [7], tepung ubi jalar ungu mengandung 7-8\% air, 2,1\% abu (bk), 58\% pati (bk), $3,0 \%$ gula reduksi (bk), dan 2,7\% serat (bk). Kandungan antosianinnya masing-masing sebesar $236,6 \mathrm{mg} / 100 \mathrm{~g}$ bb $(255,8 \mathrm{mg} / 100 \mathrm{~g}$ bk), dan $146,4 \mathrm{mg} / 100 \mathrm{~g}$ bb $(157,4 \mathrm{mg} / 100 \mathrm{~g}$ bk $)$ pada pengeringan dengan sinar matahari dan oven dengan tingkat retensi $19,7 \%$ dan $12,1 \%$. Penggunaan air dalam jumlah besar pada proses pengolahan tepung merupakan penyebab utama kehilangan antosianin, disamping pemanasan saat pengeringan. Tepung ubi jalar merupakan produk dari ubi jalar setengah jadi yang dapat digunakan sebagai bahan baku industri makanan serta berdaya simpan lebih lama. Pembuatan tepung ubi jalar ungu secara konvensional yaitu dari sawut atau chip kering yang dibuat dengan proses penggilingan dan pengayakan [9]. Tujuan dari penelitian ini adalah mempelajari sifat fisiokimia ubi jalar ungu dengan perendaman menggunakan asam sitrat.

\section{Metodologi Penelitian}

Mengupas dan mencuci ubi jalar ungu hingga bersih. Memotong setebal 0,5 $\mathrm{cm}$ dan menimbang ubi jalar ungu masing - masing variabel 250 gram. Membuat larutan asam sitrat dengan konsentrasi berbagai konsentrasi. Merendam sampel selama 18, jam. Mencuci sampel ubi jalar ungu yang telah direndam dengan menggunakan aquadest. Memotong ubi jalar ungu yang telah dicuci menggunakan parutan keju. Mengoven ubi jalar ungu yang telah diparut dengan suhu $70{ }^{\circ} \mathrm{C}$ selama 24 jam. Mengangkat dan mendinginkan simplisia ubi jalar ungu yang telah dioven. Memblender simplisia ubi jalar ungu yang telah dingin selama 3 menit. Melakukan analisis kualitatif dan fisiko kimia hasil tepung ubi jalar ungu.

\section{Hasil dan Pembahasan}

Dari hasil penelitian ini diperoleh tepung ubi jalar ungu yang secara fisik mempunyai warna just walnut, thistle dan violet, warna lebih terang dari warna asli ubi jalar ungu dikarenakan perbedaan variabel asam sitrat yang digunakan dan lama perendaman, mempunyai aroma khas ubi jalar dengan sedikit beraroma asam, tekstur tepung halus, dan kenampakan cerah. Memperkuat pendapat Winarno [1], asam sitrat juga dapat menghambat pencoklatan dengan cara menurunkan $\mathrm{pH}$. 
Table 2. Hasil Pengujian Sifat Sensori Tepung Ubi Jalar Ungu

\begin{tabular}{|c|c|c|c|c|c|c|c|c|c|}
\hline \multirow[t]{2}{*}{ Sampel } & \multirow[t]{2}{*}{ Waktu } & \multicolumn{3}{|c|}{ Warna } & \multicolumn{3}{|c|}{ Bau } & \multirow[t]{2}{*}{ Tekstur } & \multirow[t]{2}{*}{ Rendemen } \\
\hline & & 1 & 3 & 4 & 12 & 3 & 4 & & \\
\hline \multirow{6}{*}{$\begin{array}{c}\text { 0.001 } \\
\text { As sitrat: } 0.8 \mathrm{gr} \\
\text { Air: } 500 \mathrm{cc} \\
\text { Densitas asam sitrat }: 1,66 \\
\text { gr/cm }\end{array}$} & $6 \mathrm{jam}$ & & & $\sqrt{ }$ & & & $\sqrt{ }$ & Halus & 0,498 \\
\hline & $12 \mathrm{jam}$ & & & $\sqrt{ }$ & & & $\sqrt{ }$ & Halus & 0,404 \\
\hline & 18 jam & & & $\sqrt{ }$ & & & $\sqrt{ }$ & Halus & 0,395 \\
\hline & 24 jam & & $\sqrt{ }$ & & & & $\sqrt{ }$ & Halus & 0,468 \\
\hline & 30 jam & & $\sqrt{ }$ & & & & $\sqrt{ }$ & Halus & 0,408 \\
\hline & 36 jam & & $\sqrt{ }$ & & & & $\sqrt{ }$ & Halus & 0,445 \\
\hline \multirow{6}{*}{$\begin{array}{c}0.0025 \\
\text { As sitrat: } 2.1 \mathrm{gr} \\
\text { Air: } 500 \mathrm{cc}\end{array}$} & 6 jam & & & $\sqrt{ }$ & & & $\sqrt{ }$ & Halus & 0,527 \\
\hline & 12 jam & & & $\sqrt{ }$ & & & $\sqrt{ }$ & Halus & 0,463 \\
\hline & 18 jam & & $\sqrt{ }$ & & & & $\sqrt{ }$ & Halus & 0,483 \\
\hline & 24 jam & & $\sqrt{ }$ & & & & $\sqrt{ }$ & Halus & 0,428 \\
\hline & 30 jam & & $\sqrt{ }$ & & & & $\sqrt{ }$ & Halus & 0,596 \\
\hline & 36 jam & $\sqrt{1}$ & & & & $\sqrt{ }$ & & Halus & 0,445 \\
\hline \multirow{6}{*}{$\begin{array}{c}0,01 \\
\text { As sitrat: } 8.3 \mathrm{gr} \\
\text { Air: } 500 \mathrm{cc}\end{array}$} & $6 \mathrm{jam}$ & & & $\sqrt{ }$ & & & $\sqrt{ }$ & Halus & 0,611 \\
\hline & $12 \mathrm{jam}$ & & & $\sqrt{ }$ & & & $\sqrt{ }$ & Halus & 0,425 \\
\hline & 18 jam & & & $\sqrt{ }$ & & $\sqrt{ }$ & & Halus & 0,446 \\
\hline & 24 jam & & $\sqrt{ }$ & & & $\sqrt{ }$ & & Halus & 0,601 \\
\hline & 30 jam & $\sqrt{ }$ & & & & $\sqrt{ }$ & & Halus & 0,490 \\
\hline & 36 jam & $\sqrt{1}$ & & & & $\sqrt{ }$ & & Halus & 0,471 \\
\hline \multirow{6}{*}{$\begin{array}{c}0,015 \\
\text { As sitrat: } 12.5 \mathrm{gr} \\
\text { Air: } 500 \mathrm{cc}\end{array}$} & $6 \mathrm{jam}$ & & $\sqrt{ }$ & & & & $\sqrt{ }$ & Halus & 0,405 \\
\hline & 12 jam & & $\sqrt{ }$ & & & & $\sqrt{ }$ & Halus & 0,608 \\
\hline & 18 jam & & $\sqrt{ }$ & & & $\sqrt{ }$ & & Halus & 0,283 \\
\hline & 24 jam & $\sqrt{1}$ & & & & $\sqrt{ }$ & & Halus & 0,357 \\
\hline & $30 \mathrm{jam}$ & $\sqrt{ }$ & & & & $\sqrt{ }$ & & Halus & 0,545 \\
\hline & 36 jam & $\sqrt{1}$ & & & & $\sqrt{ }$ & & Halus & 0,650 \\
\hline \multirow{6}{*}{$\begin{array}{c}0,02 \\
\text { As sitrat: } 16,7 \mathrm{gr} \\
\text { Air: } 500 \mathrm{cc}\end{array}$} & 6 jam & & $\sqrt{ }$ & & & $\sqrt{ }$ & & Halus & 0,456 \\
\hline & 12 jam & & $\sqrt{ }$ & & & $\sqrt{ }$ & & Halus & 0,623 \\
\hline & 18 jam & & $\sqrt{ }$ & & & $\sqrt{ }$ & & Halus & 0,392 \\
\hline & 24 jam & $\sqrt{ }$ & & & & $\sqrt{ }$ & & Halus & 0,195 \\
\hline & 30 jam & 1 & & & & $\sqrt{ }$ & & Halus & 0,553 \\
\hline & 36 jam & $v$ & & & & $\sqrt{ }$ & & Halus & 0,597 \\
\hline
\end{tabular}

Untuk dapat membedakan warna yang dihasilkan dari setiap sampel tepung tersebut maka dibuat range 1-4, dimana range 1 merupakan warna yang paling terang sampai range 4 warna yang paling gelap. Sampel variabel $0,001 \%$ memiliki warna just walnut, dimana just walnut 4 memiliki warna paling gelap, just walnut 3 memiliki warna agak gelap, just walnut 2 memiliki warna agak terang, dan just walnut 1 memiliki warna paling terang. Untuk sampel variabel $0,0025 \%$ memiliki warna thistle, dimana thistle 4 memiliki warna paling gelap, thistle 3 memiliki warna agak gelap, thistle 2 memiliki warna agak terang, dan thistle 1 memiliki warna paling terang. Sedangkan pada sampel $0,01 \%, 0,015 \%$ dan $0,02 \%$ memiliki warna violet, dimana violet 4 memiliki warna paling gelap, violet 3 memiliki warna agak gelap, violet 2 memiliki warna agak terang, dan violet 1 memiliki warna paling terang. Untuk membedakan bau dari tepung ubi jalar ungu dari setiap sampel maka dibuat range 1-4, dimana range 1 memiliki bau yang sangat asam, range 2 memiliki bau asam, range 3 memiliki bau sedikit asam sampai range 4 memiliki bau yang sangat sedikit asam.

Adapun fungsi bahan yang digunakan dalam percobaan pembuatan tepung ini adalah perendaman dengan larutan asam sitrat yang berfungsi secara signifikan sebagai anti pencoklatan selama pengolahan dan penyimpanan. Terlihat hal tersebut pada hasil tepung dengan penggunaan setiap kenaikan variabel asam sitrat diperoleh warna tepung yang semakin meningkat kecerahannya seperti pada penggunaan asam sitrat dengan konsentrasi $0,02 \%$ dan hasil tepung ubi jalar ung dapat dilihat pada gambar 1. Asam sitrat ini juga dapat mencegah ketengikan pada produk yang dihasilkan, sebagai larutan penyangga atau buffer yang mampu mempertahankan $\mathrm{pH}$ agar tidak banyak berubah saat perendaman. 
Tepung ubi jalar ungu ini mempunyai tekstur yang halus, karena pada saat proses perendaman dilakukan secara anaerob sehingga karbohidrat dan serat yang terdapat pada ubi jalar ungu tersebut menjadi lebih lunak dan mudah hancur.

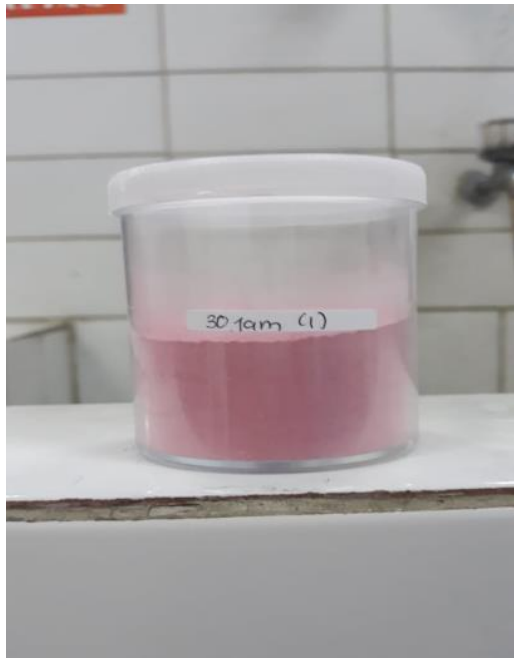

Sampel 1

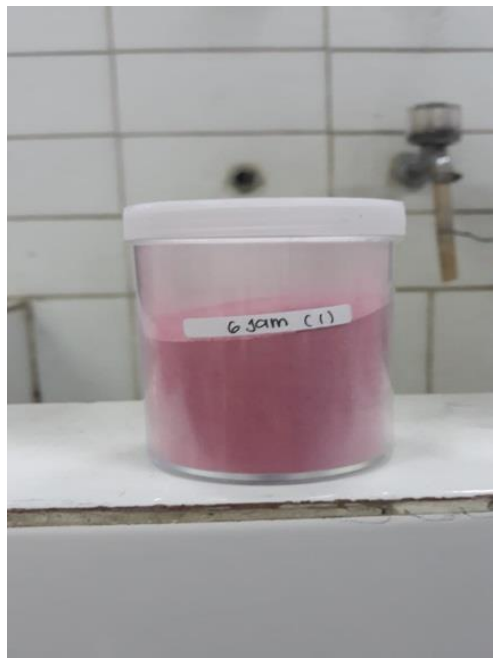

Sampel 2

Gambar 1. Sampel Tepung Ubi Jalar Ungu 30 Jam dan 6 Jam

Hasil analisa fisiko kimia untuk pembuatan tepung terigu terbaik yaitu perendaman dengan $0,01 \%$ asam sitrat selama 12 jam terdapat pada tabel 2 . Kadar abu tepung ubi jalar ungu sebesar 1,69\% lebih tinggi dari tepung terigu namun lebih rendah dari hasil penelitian Kusumawardani [7], meskipun kandungan serat pangannya lebih tinggi. Kandungan pati ubi jalar ungu hasil penelitian hampir sama dengan tepung terigu seperti terdapat pada tabel 3, lebih tinggi dari hasil penelitian Kusumawardani [7].

Table 3. Hasil Analisa Kandungan Makro Tepung Terigu, Tepung Ubi Jalar Ungu

\begin{tabular}{clcc}
\hline No. & Jenis analisa & Tepung terigu & Tepung ubi jalar ungu \\
\hline $\mathbf{1}$ & Air & $12,9 \%$ & $9,85 \%$ \\
\hline $\mathbf{2}$ & Abu & $0,35 \%$ & $1,69 \%$ \\
\hline $\mathbf{3}$ & Protein & $11,1 \%$ & $3,75 \%$ \\
\hline $\mathbf{4}$ & Lemak & $0,13 \%$ & $0,67 \%$ \\
\hline $\mathbf{5}$ & Serat pangan & $1,53 \%$ & $8,8 \%$ \\
\hline $\mathbf{6}$ & Pati & $71,6 \%$ & $72,8 \%$ \\
\hline $\mathbf{7}$ & Glukosa & $0,4 \%$ & $2,05 \%$ \\
\hline
\end{tabular}

\section{Kesimpulan}

Perendaman ubi jalar ungu menggunakan asam sitrat $0,01 \%$ menghasilkan tepung ubi jalar ungu yang berwarna cerah, tepung halus, menurunkan kandungan abu dengan bau tepung sangat sedikit asam.

\section{Daftar Pustaka}

[1] Winarno, F.G. 2002. Kimia Pangan dan Gizi. PT Gramedia Pustaka Utama. Jakarta.

[2] Purwanto, B.H. (2012). Interaksiantarbahanterlarut. http://benito.staff.ugm.ac.id. [17 Maret 2012].

[3] Abbasi, N.A., Attiq Akhtar, Azhar Husain, and Irfan A.2013. Effect of Anti-Browning Agents On Quality Changes of loquat [Eriobotrya japonica (Thunb.) Lindley] Fruit After Harvest.J. Bot. 45(4): 1391-1396.

[4] Woolfe, J. A., 1999, Sweet Potato: an Untapped Food Resources, Chapman and Hall, New York. 
[5] Susilawati dan Medikasari, 2008, Kajian Formulasi Tepung Terigu dan Tepung dari Berbagai Jenis Ubi Jalar Sebagai Bahan Dasar Pembuatan Biskuit Non-Flaky Crackers, Prosiding Seminar Nasional Sains dan Teknologi II 2008, Universitas Lampung, 17-18 November 2008.

[6] Ginting, E., Y. Widodo, S.A. Rahayuningsih, dan M. Jusuf, 2005, Karakteristik Pati Beberapa Varietas Ubi Jalar, Jurnal Tanaman Pangan, Vol. 24(1), http//:puslittan.bogor.net. (29-04-2009).

[7] Kusumawardani, L. S., 2008, Pengaruh pengolahan tepung terhadap sifat fisik kimia serta retensi $\beta$ karoten pada ubijalar oranye dan antosianin pada ubijalar ungu, Skripsi S1, Jurusan Teknologi Hasil Pertanian, Fakultas Teknologi Pertanian Universitas Brawijaya, Malang.

[8] Antarlina, S. S. dan M. Jusuf, 2001, Pengolahan tepung ubi jalar beberapa varietas pada umur panen yang berbeda, Prosiding Seminar Nasional Inovasi Alat dan Mesin Pertanian untuk Agribisnis, Badan Litbang Pertanian-Perteta, Jakarta, p. 227-235.

[9] Richana, N. 2012. Ubi Kayu dan Ubi Jalar. Nuansa. Bandung. 